Article

\title{
Green Binder Based on Enzymatically Polymerized Eucalypt Kraft Lignin for Fiberboard Manufacturing: A Preliminary Study
}

\author{
Susana Gouveia ${ }^{1}$ (D), Luis Alberto Otero ${ }^{2}$, Carmen Fernández-Costas ${ }^{1}$, Daniel Filgueira ${ }^{1}$ (D), \\ Ángeles Sanromán ${ }^{1}$ and Diego Moldes ${ }^{1, *}$ (1) \\ 1 Department of Chemical Engineering, University of Vigo, Lagoas Marcosende s/n., E-36310 Vigo, Spain; \\ gouveia@uvigo.es (S.G.); mcarmenfc@uvigo.es (C.F.-C.); danmartinez@uvigo.es (D.F.); \\ sanroman@vigo.es (Á.S.) \\ 2 R \& D Department of FORESA, Avda, Doña Urraca, 91, Caldas de Reis, 36650 Pontevedra, Spain; \\ 1.otero@foresa.com \\ * Correspondence: diego@uvigo.es; Tel.: +34-986-818-723
}

Received: 10 April 2018; Accepted: 7 June 2018; Published: 9 June 2018

\begin{abstract}
The capability of laccase from Myceliophthora thermophila to drive oxidative polymerization of Eucalyptus globulus Kraft lignin (KL) was studied as a previous step before applying this biotechnological approach for the manufacturing of medium-density fiberboards (MDF) at a pilot scale. This method, which improves the self-bonding capacity of wood fibers by lignin enzymatic cross-linking, mimics the natural process of lignification in living plants and trees. An interesting pathway to promote these interactions could be the addition of lignin to the system. The characterization of E. globulus KL after enzymatic treatment showed a decrease of phenolic groups as well as the aromatic protons without loss of aromaticity. There was also an extensive oxidative polymerization of the biomolecule. In the manufacture of self-bonded MDF, the synergy generated by the added lignin and laccase provided promising results. Thus, whenever laccase was present in the treatment, MDF showed an increase in mechanical and dimensional stability for increasing amounts of lignin. In a pilot scale, this method produced MDF that meets the requirements of the European standards for both thickness swell (TS) and internal bonding (IB) for indoor applications.
\end{abstract}

Keywords: wood; Eucalyptus globulus; laccase; Kraft lignin; medium-density fiberboards; pilot scale

\section{Introduction}

Currently, the wood-based panels industry needs to find natural substitutes of synthetic resins to be a sustainable and eco-friendly industry. The bonding of wood components is achieved when a resinous matrix is formed. The wood boards produced with conventional gluing process show high mechanical strength and relative low swelling when exposed to water.

Up to the present, a great deal of research has been devoted to reducing the environmental impact of wood-based panels industries, more concretely the impact of oil-derived adhesives such as urea-formaldehyde or phenol-formaldehyde. Replacement of fossil phenol by biomass-derived phenols (e.g., lignin, tannins) seems to be a sustainable and environmentally friendly approach [1-3]. However, these authors substituted phenol with lignin, but the binders still included formaldehyde, a toxic compound with a significant impact in human health and environment. It is worth noting that the manufacturing of wood-based panels requires the bonding of wood elements, and such unions are due not only to the effect of synthetic resins but also by the intrinsic auto-adhesive properties of wood compounds $[4,5]$. The auto-adhesive ability suggests that a more environmentally friendly 
approach to reduce the use of resins is to boost up the inherent capacity of wood elements to bind among themselves.

Most of the studies related to the quest of a binderless fiberboard manufacture process are based on the oxidative modification of lignin [6,7]. The chemical structure of lignin possesses a broad range of chemical groups, i.e., hydroxyl (aliphatic and aromatic), methoxyl, carboxyl or carbonyl, which converts lignin in a raw material with several potential applications [8]. Moreover, such renewable biopolymer is industrially available because it is separated from the polysaccharides during the pulping process of lignocellulosic biomass. Nonetheless, technical lignins, mainly Kraft lignin (KL), are considered by-products and their use is normally limited to energy production in the pulp mills.

The use of phenol-oxidizing enzymes (e.g., laccases, peroxidases) for adhesive applications is based on the capability of enzymes to promote the polymerization and cross-linking of lignin $[4,9,10]$ (Figure S1). The effects of laccases [11-14] and peroxidases [15,16] over the chemical structure of lignin has been examined by several studies. The authors concluded that both enzymes promote the oxidation of the phenolic groups to phenoxy radicals in a one-electron oxidation. Hence, the incubation of wood fibers with phenol oxidizing enzymes results in the cross-linking of lignin moieties by means of covalent bonds $[4,17]$. Such mechanism enables the wood fibers adhesion, leading to the manufacturing of wood-based panels with substantial improvements in both mechanical and physical properties. Among the wood composite panels, the manufacturing process for medium-density fiberboards (MDF) has some characteristics which make it particularly suitable for the use of this biotechnology.

The aim of this study is to test the laccase-assisted enzymatic treatment for the manufacturing of binderless Eucalyptus globulus fiberboard at pilot scale. Thus, a two-component system manufacturing process adding KL to wood fibers was tested and the effect of incubation time as well as the amount of lignin added to the board was studied. The effect on the physical and mechanical properties of the resulting wood boards was assessed. To a better understanding of the enzymatic reactions involving lignin during fiber enzymatic treatments, isolated KL was subjected to the same treatment and comparative studies of the lignins, before and after enzymatic action, were performed by several analytical techniques (FTIR, HPLC-SEC, 2D NMR).

The MDF manufacturing process tested in this study is presented as an interesting lignin valorization in the context of circular economy with the additional environmental benefits of removing toxic binding materials from the conventional manufacturing process.

\section{Materials and Methods}

\subsection{Lignin}

Black liquor from the Kraft cooking process of Eucalyptus globulus was supplied by ENCE (Pontevedra, Spain). Kraft lignin (KL) was obtained by acidic precipitation of the black liquor as follows. Black liquor was diluted in water (1:1) and the $\mathrm{pH}$ was lowered to 2.5 by addition of sulfuric acid $4 \mathrm{M}$. The solution was left under stirring for $30 \mathrm{~min}$. The precipitate was centrifuged, and the isolated $\mathrm{KL}$ was washed twice with acidified water $(\mathrm{pH} 2.5)$. KL was oven-dried overnight at $60^{\circ} \mathrm{C}$, and then it was milled in an agate mortar and stored in amber glass bottle until use.

\subsection{Laccase Enzyme}

Laccase from Myceliophthora thermophila (NS51003) was kindly supplied by Novozymes (Bagsvaerd, Denmark). Commercial laccase was desalted using a PD-10 desalting column with Sephadex G-25 Medium (General Electric, Norwalk, CT, USA) following the supplier recommended protocol.

Laccase activity was determined spectrophotometrically by oxidation of 2,2'-azino-bis (3-ethylbenzothiazoline-6-sulphonic acid) (ABTS) at $436 \mathrm{~nm}\left(\varepsilon=29300 \mathrm{M}^{-1} \mathrm{~cm}^{-1}\right)$ in potassium phosphate buffer $\mathrm{pH} 7.3$ at $25^{\circ} \mathrm{C}$. One activity unit (U) was defined as the amount of enzyme that oxidized $1 \mu \mathrm{mol}$ of substrate per min. 


\subsection{Wood Fibers}

Eucalyptus globulus fibers were supplied by the MDF board plant of FINSA industries (Padrón, Spain). The fibers were dried in a flash drier until a moisture content of $2 \%$.

\subsection{KL Enzymatic Polymerization}

Lignin was solubilized in phosphate buffer $\mathrm{pH} 7.3(100 \mathrm{mM})$ obtaining a solution of $1.5 \mathrm{~g} \cdot \mathrm{L}^{-1}$. The desalted laccase was added to $90 \mathrm{~mL}$ of the latter solution to reach a final activity of $2 \mathrm{U} \cdot \mathrm{mL}^{-1}$. The reaction took place at $70{ }^{\circ} \mathrm{C}$ for $2 \mathrm{~h}$ in an orbital shaker. The reaction was stopped by lowering the $\mathrm{pH}$ to 2.0 causing enzyme deactivation and lignin precipitation. The reaction product was filtered and washed twice with acidified water ( $\mathrm{pH}$ 2.5) and oven-dried at $60^{\circ} \mathrm{C}$ overnight.

\subsection{KL Characterization}

\subsubsection{Determination of Phenolic Content}

Phenolic content was evaluated as described by [18]. Initially, KL solutions of $0.5 \mathrm{~g} \cdot \mathrm{L}^{-1}$ in $\mathrm{NaOH}$ $0.05 \mathrm{M}$ were prepared. Then, $1 \mathrm{~mL}$ of KL solution, $3 \mathrm{~mL}$ of Folin and Ciocalteu reagent and $30 \mathrm{~mL}$ of distilled water were added into a volumetric flask and mixed thoroughly. After 5-8 min of stirring, $10 \mathrm{~mL}$ of $20 \%(w / w)$ sodium carbonate solution was added and the volume was adjusted to $50 \mathrm{~mL}$ with DI (deionized) water. The mixture was stirred for $2 \mathrm{~h}$ and finally, the absorbance at $760 \mathrm{~nm}$ was measured. The phenolic content test was run in duplicate. Vanillin standard solutions $(0-5 \mathrm{mM})$ were used for calibration.

\subsubsection{Fourier Transform Infrared Spectroscopy (FTIR)}

Solid KL samples were placed to dry for 10 min under an infrared lamp. The FTIR spectra were recorded with a Jasco FT/IR-4100 (Easton, PA, USA), equipped with attenuated total reflectance (ATR) in absorbance mode using a frequency range of $650-4000 \mathrm{~cm}^{-1}$. Each spectrum, which accumulated 32 scans at $4 \mathrm{~cm}^{-1}$ resolution, was then analyzed with the OMNIC 32 software.

The absorption bands were assigned as suggested by [19]. The spectrum was baselined and ATR corrected and the bands intensities were normalized referring aromatic skeletal vibration (around $\left.1510 \mathrm{~cm}^{-1}\right)$.

\subsubsection{Molecular Weight Distribution}

Lignin samples were dissolved in $\mathrm{NaOH} 0.05 \mathrm{M}$ (final concentration of $0.5 \mathrm{~g} \cdot \mathrm{L}^{-1}$ ), and left in agitation for $8 \mathrm{~h}$ at $300 \mathrm{rpm}$ and $40^{\circ} \mathrm{C}$. Once totally dissolved, the samples were filtrated with PVDF $0.2 \mu \mathrm{m}$ syringe filter.

Size-exclusion chromatography was performed in a Jasco HPLC system (Easton, PA, USA) (AS 1555 auto sampler; PU 2080 plus pump, UV 975 detector) equipped with two GPC columns (Phenomenex, Torrance, CA, USA) coupled in series (GPC P4000 and P5000, both $300 \mathrm{~mm} \times 7.8 \mathrm{~mm}$ ) and a safeguard column $(35 \mathrm{~mm} \times 7.8 \mathrm{~mm})$. The injection volume was $100 \mu \mathrm{L}$, and the isocratic flow $(\mathrm{NaOH} 0.05 \mathrm{M})$ was pumped at a rate of $1 \mathrm{~mL} \cdot \mathrm{min}^{-1}$ at $25^{\circ} \mathrm{C}$ for $26 \mathrm{~min}$. Detection was performed with a UV detector at $254 \mathrm{~nm}$. Data was recorded and analyzed with ChromNAV GPC software. Calibration curve was obtained with polystyrene polymer standards (Phenomenex) with molecular weights of $891,1670,6430,10,200,33,500,65,400,158,000,305,000,976,000$ and 2,350,000 Da. Concentrations and injection volumes were performed according to the manufacturer's specifications. The mobile phase was the same used as solvent for KL samples, i.e., $0.05 \mathrm{M} \mathrm{NaOH}$.

\subsubsection{Nuclear Magnetic Resonance (NMR)}

NMR techniques, namely proton nuclear magnetic resonance spectroscopy $\left({ }^{1} \mathrm{H}\right)$, carbon nuclear magnetic resonance spectroscopy $\left({ }^{13} \mathrm{C}\right)$ and Heteronuclear Single Quantum Coherence (HSQC) were 
used for KL characterization. KL samples were previously acetylated to enhance their solubility in the NMR solvent. An adaptation of the method described by [20] was performed to acetylate the samples. Approximately $100 \mathrm{mg}$ of KL was placed in a dry acetylation vial and $500 \mu \mathrm{L}$ of pyridine were added. The vial was sealed and constantly stirred at $37^{\circ} \mathrm{C}$ during $1 \mathrm{~h}$ or until the KL full sample dissolution. Afterwards, $1 \mathrm{~mL}$ of acetyl anhydride was added and left reacting with constant agitation at $37^{\circ} \mathrm{C}$ for $48 \mathrm{~h}$. Finally, once the acetylation process was over, $440 \mu \mathrm{L}$ of methanol were added to remove the excess of pyridine and acetyl anhydride. After $2 \mathrm{~h}$ of stirring, the content of the vial was dried and milled with and agate mortar and pestle.

All spectra have been recorded at $25^{\circ} \mathrm{C}$ on a Bruker Avance $400 \mathrm{MHz}$ (Billerica, MA, USA), equipped with a z-gradient 5-mm QNP probe. Chemical shifts were referred to the solvent signals, $\delta\left({ }^{1} \mathrm{H}\right)=2.5 \mathrm{ppm}, \delta\left({ }^{13} \mathrm{C}\right)=39.5 \mathrm{ppm}$.

\section{${ }^{1} \mathrm{H}$ NMR}

$50 \mathrm{mg}$ of both acetylated and non-acetylated KL were dissolved in $750 \mu \mathrm{L}$ of deuterated dimethyl sulfoxide (DMSO-d6). The relaxation delay was $1 \mathrm{~s}$ and a flip angle of $30^{\circ}$ was used. The number of scans was 16 with an acquisition time of $6.3 \mathrm{~s}$. Spectra were processed using an exponential weighting function of $0.3 \mathrm{~Hz}$ prior to Fourier transformation.

\section{${ }^{13} \mathrm{C}$ NMR}

$50 \mathrm{mg}$ of KL were dissolved in $750 \mu \mathrm{L}$ of DMSO- $d 6$. The relaxation delay was $5 \mathrm{~s}$, and a flip angle of $30^{\circ}$ was used. The number of scans was 50,000 with an acquisition time of $1.4 \mathrm{~s}$.

\section{HSQC}

KL samples (150 mg) were dissolved in $750 \mu \mathrm{L}$ of DMSO- $d 6$. The number of complex points collected was 2048 for the ${ }^{1} \mathrm{H}$ dimension and a recycle delay of $5.28 \mathrm{~s}(5 \mathrm{~s}$ relaxation delay and $0.28 \mathrm{~s}$ acquisition time) was chosen. The number of transients was 128 and 256 time increments were recorded in the ${ }^{13} \mathrm{C}$ dimension.

\subsection{Medium-Density Fiberboards Production}

\subsubsection{Enzymatic Fiber Pre-Treatments}

E. globulus fibers were submitted to different treatments as listed in Table 1. Regarding to one-component system, laccase was air-pressurized sprayed to the dried fibers on a rotary drum blender until homogenization. However, in the case of two-component system (fiber and KL), KL was premixed with the fibers in the rotary blender prior to enzyme addition. Enzyme was added as commercially supplied and no $\mathrm{pH}$ adjustment was carried out. After homogenization, to allow sufficient time for the enzymatic reactions take place, fibers (or fibers and added KL) were left in an oven at $70{ }^{\circ} \mathrm{C}$ for $2 \mathrm{~h}$, in a vessel without agitation. The vessel was covered with aluminum foil to avoid water evaporation, except when initial moisture was $20 \%$ or higher; in such cases the vessel was uncovered, and the moisture controlled every $30 \mathrm{~min}$ to ensure minimum moisture of $10-12 \%$. 
Table 1. Experimental conditions and fiberboards composition.

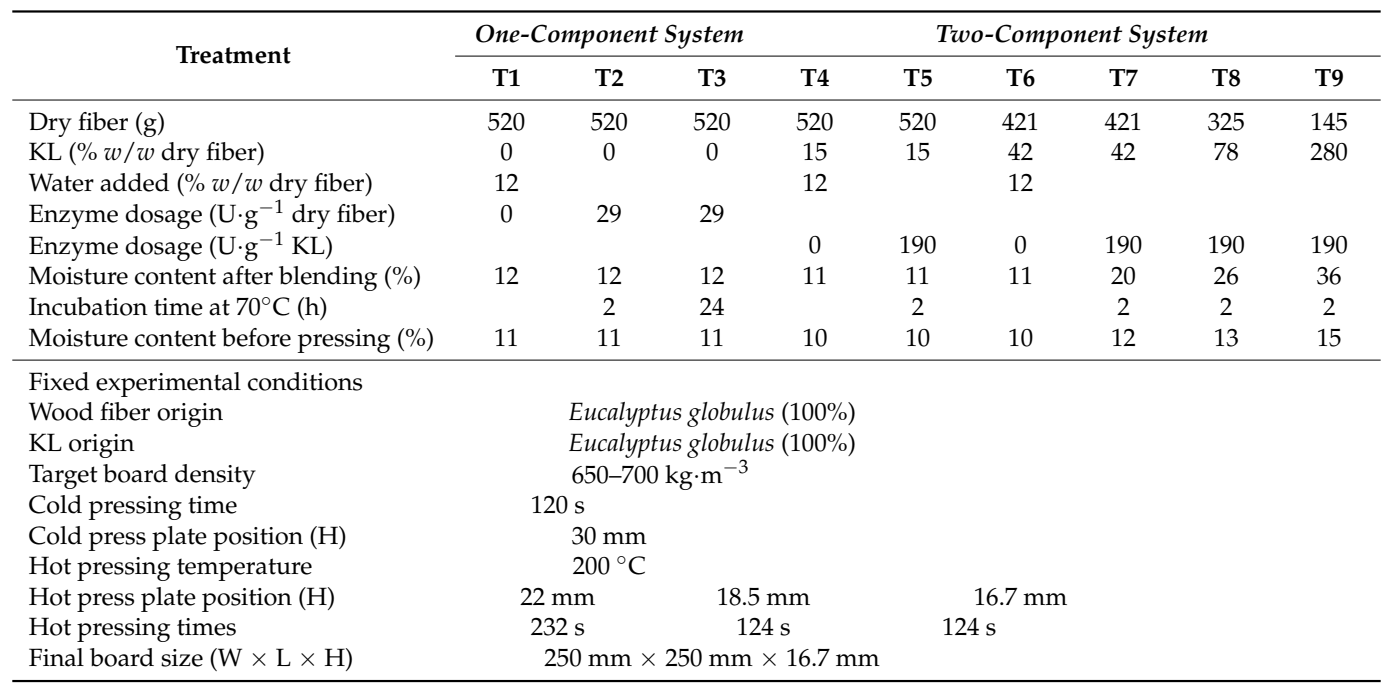

\subsubsection{MDF Preparation}

After the enzymatic treatment, fibers were pressed in a mold, producing an approximately cubic mat $(\approx 250 \mathrm{~mm} \times 250 \mathrm{~mm} \times 250 \mathrm{~mm})$. The resulting mat was cold pressed for about $2 \mathrm{~min}$ to an approximate height of $40 \mathrm{~mm}$. The mat was taken in hot press (press platens were maintained at $200^{\circ} \mathrm{C}$ ) and reduced to its final thickness in a dynamic three step cycle with a total time of $8 \mathrm{~min}$. In step one, the mat was pressed to $22 \mathrm{~mm}$ for $232 \mathrm{~s}$ and, in the second and third step, the board was pressed to a height of $18.5 \mathrm{~mm}$ and $16.7 \mathrm{~mm}$ respectively, both for $124 \mathrm{~s}$.

The complete manufacturing process is described in Figure 1, and the process parameters are summarized in Table 1.
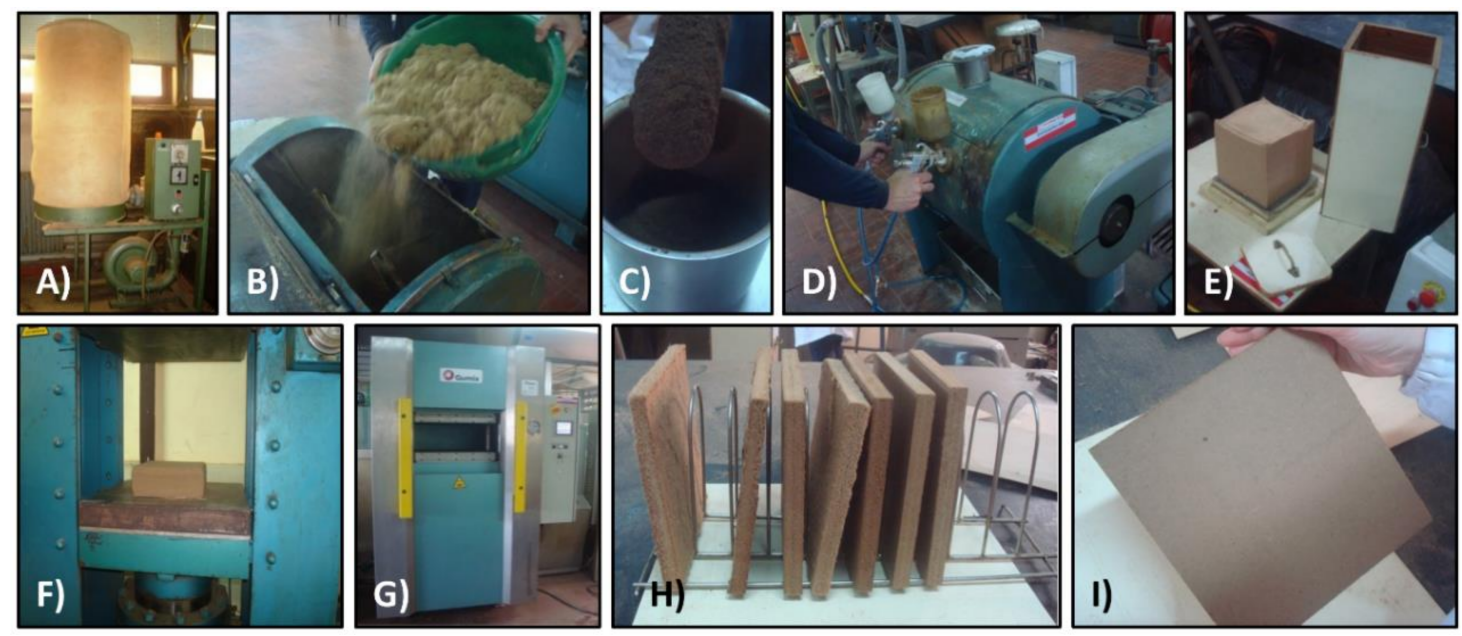

Figure 1. Binderless MDF pilot scale manufacturing procedure: (A) Drying of eucalyptus fibers; (B) Addition of fibers with $2 \%$ moisture to drum blender; (C) E. globulus KL addition; (D) Laccase spraying with air pressure; (E) Mat manually pressed; (F) Mat cold pressing; (G) 3 steps hot pressing cycle; $(\mathbf{H}, \mathbf{I})$ Final MDF boards.

\subsubsection{Medium-Density Fiberboard Properties}

The internal bond strength (IB) was determined according to EN 319 [21]. Thickness swell (TS) and water absorption (WA) were determined using specimens of $(50 \pm 1) \mathrm{mm} \times(50 \pm 1) \mathrm{mm}$. After an aging cycle where the specimens were submersed for $24 \mathrm{~h}$ in an upright position in water at 20 
${ }^{\circ} \mathrm{C}$, the excess of water was drained. Specimen's thickness and mass was measured prior and after the immersion.

\section{Results and Discussion}

\subsection{Kraft Lignin Enzymatic Polymerization and Characterization}

Laccase enzyme is one of the most inexpensive enzymes widely available in the market. Commercial laccase from $M$. thermophila showed the ability to oxidize and polymerize Kraft lignin (KL). The extension of this polymerization depended on several parameters such as lignin origin, $\mathrm{pH}$, temperature, phenolic mediators or reaction time $[11,12,22,23]$. The aim of this study was to test the capability of the enzymatic treatment of KL in the manufacturing of MDF with no synthetic resins. The enzymatic treatment was tested to enhance the cross-linking among lignin molecules to produce stable and durable MDF from E. globulus fibers and KL. The experimental conditions used in these studies were those previously identified to favor the enzymatic polymerization of E. globulus KL [11].

The oxidative enzymatic treatment of KL with laccase induced clear changes in the structure of lignin as it was observed in the reaction vessel during the reaction. Hence, the resulting enzymatically-treated lignin showed a much darker brown color compared to the original lignin. Moreover, the polymerized KL required a very long stirring time (1 day) to be dissolved in $\mathrm{NaOH}$ $0.05 \mathrm{M}$ whereas the original KL was easily dissolved in just a few seconds. Gel permeation chromatography, phenolic content, FTIR and NMR $\left({ }^{1} \mathrm{H},{ }^{13} \mathrm{C}\right.$ and HSQC) analyses were used to characterize the enzymatically-polymerized KL. Detailed analytical procedures, results and discussion can be found in previous publications $[11,12,24]$. Gel permeation chromatography permits to compare the average molecular weight of the original and polymerized KL (Figure S2). As observed in Figure 2A, the enzymatically-treated KL showed a strong increase in the average molecular weight (17-fold) compared to the original KL. At the same time, the enzymatic polymerization was associated with a loss of the lignin's phenolic content (Figure 2B). Such results evidenced that laccase oxidized the KL's phenolic moieties to phenoxy radicals, which were coupled among themselves leading to a remarkable increase in the molecular weight and a lower phenolic content of the KL. The FTIR spectra analyses of both polymerized and original KL detected that polymerized KL showed a higher signal of the peaks associated with $\mathrm{C}=\mathrm{O}$ bonds, for both non-conjugated $\left(1718-1703 \mathrm{~cm}^{-1}\right)$ and conjugated $\mathrm{C}=\mathrm{O}$ bonds (1655-1654 $\mathrm{cm}^{-1}$ ) (Figure S3). It is important to stress that the conjugated $\mathrm{C}=\mathrm{O}$ were not detected in the original KL (Figure 2C).

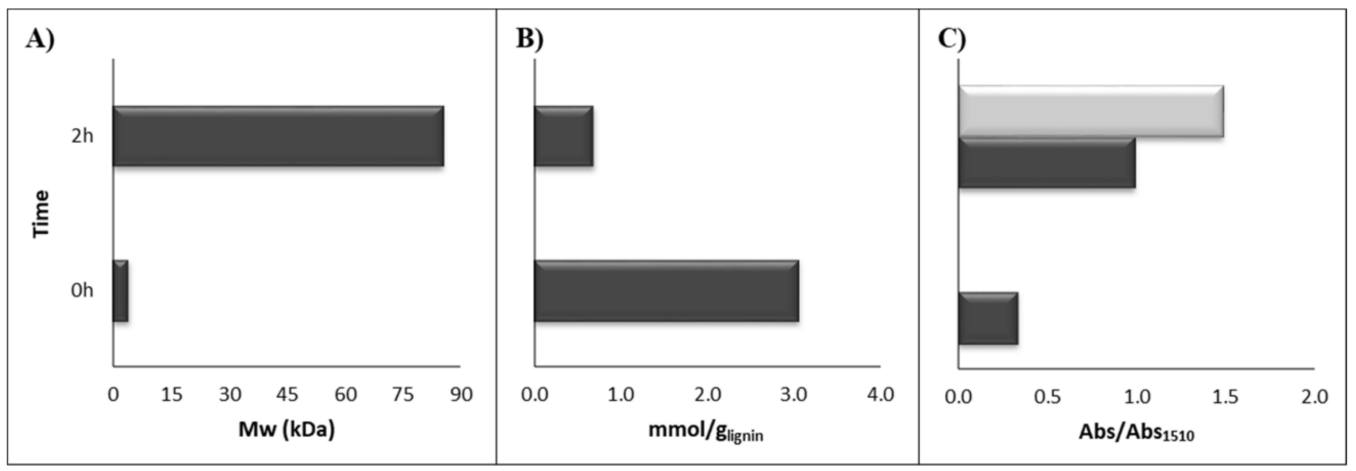

Figure 2. Comparison between untreated $(0 \mathrm{~h})$ and enzymatically treated $(2 \mathrm{~h})$ E. globulus KL: (A) Molecular weight; (B) Phenolic content; (C) Conjugated C=O FTIR absorbance referenced to aromatic skeletal vibration (light gray) and non-conjugated $\mathrm{C}=\mathrm{O}$ FTIR absorbance referenced to aromatic skeletal vibration (dark gray).

NMR techniques, particularly 2D-NMR such as HSQC, are powerful tools in the identification and quantification of lignin main structures $[25,26] .{ }^{1} \mathrm{H}$ NMR analysis of non-acetylated KL (Figure 3) 
indicates a pronounced decrease of the aromatic protons in KL after laccase-mediated polymerization. The comparison of ${ }^{1} \mathrm{H}$ NMR spectra, before and after polymerization, shows a wide band associated to methoxyl groups (4.2-3.1 ppm) after enzymatic treatment whereas most of the aromatic protons disappeared (7.0-6.0 ppm). In addition, benzaldehyde protons, with a chemical shift of $9.78 \mathrm{ppm}$, also disappeared after the polymerized KL. The disappearance of aromatic proton signals was not totally unexpected as it has been previously reported with lignosulfonates by [27].

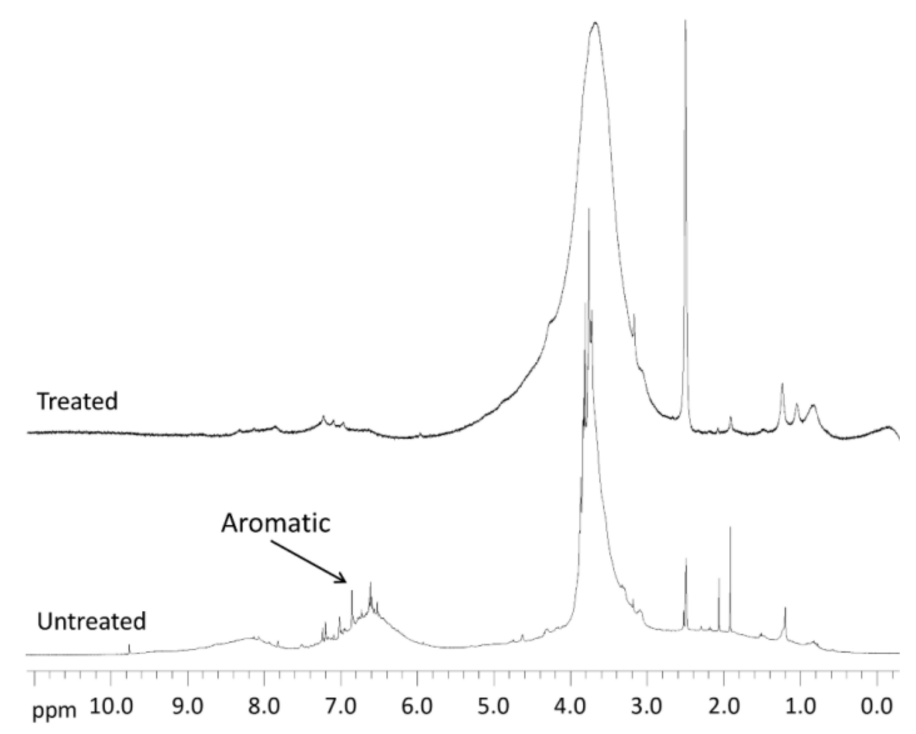

Figure 3. ${ }^{1} \mathrm{H}$ NMR spectra of non-acetylated E. globulus Kraft lignin samples.

Sample acetylation improved the KL solubilization and allows differentiating the aliphatic from the aromatic hydroxyl groups. However, the process of acetylation caused structural changes and the spectra obtained for the acetylated samples showed poorer signals. Nevertheless, ${ }^{1} \mathrm{H}$ NMR analysis of acetylated samples (Figure 4) evidenced that nearly all aromatic hydroxyls have been attacked by laccase while some aliphatic hydroxyls remained in the polymerized KL.

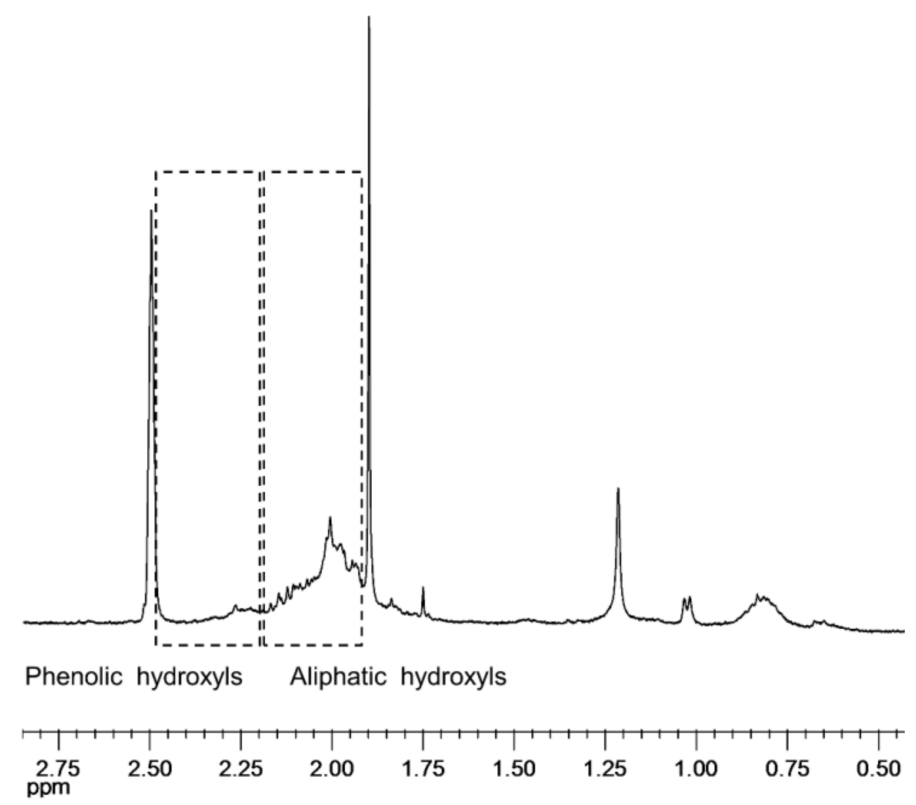

Figure 4. Expanded region of ${ }^{1} \mathrm{H}$ NMR spectrum of an enzymatically treated E. globulus KL subjected to acetylation. 
This result was even clearer in the HSQC spectrum (Figure 5), where there was no correlation for aromatic hydroxyls and there was only a small area corresponding to the aliphatic hydroxyls.

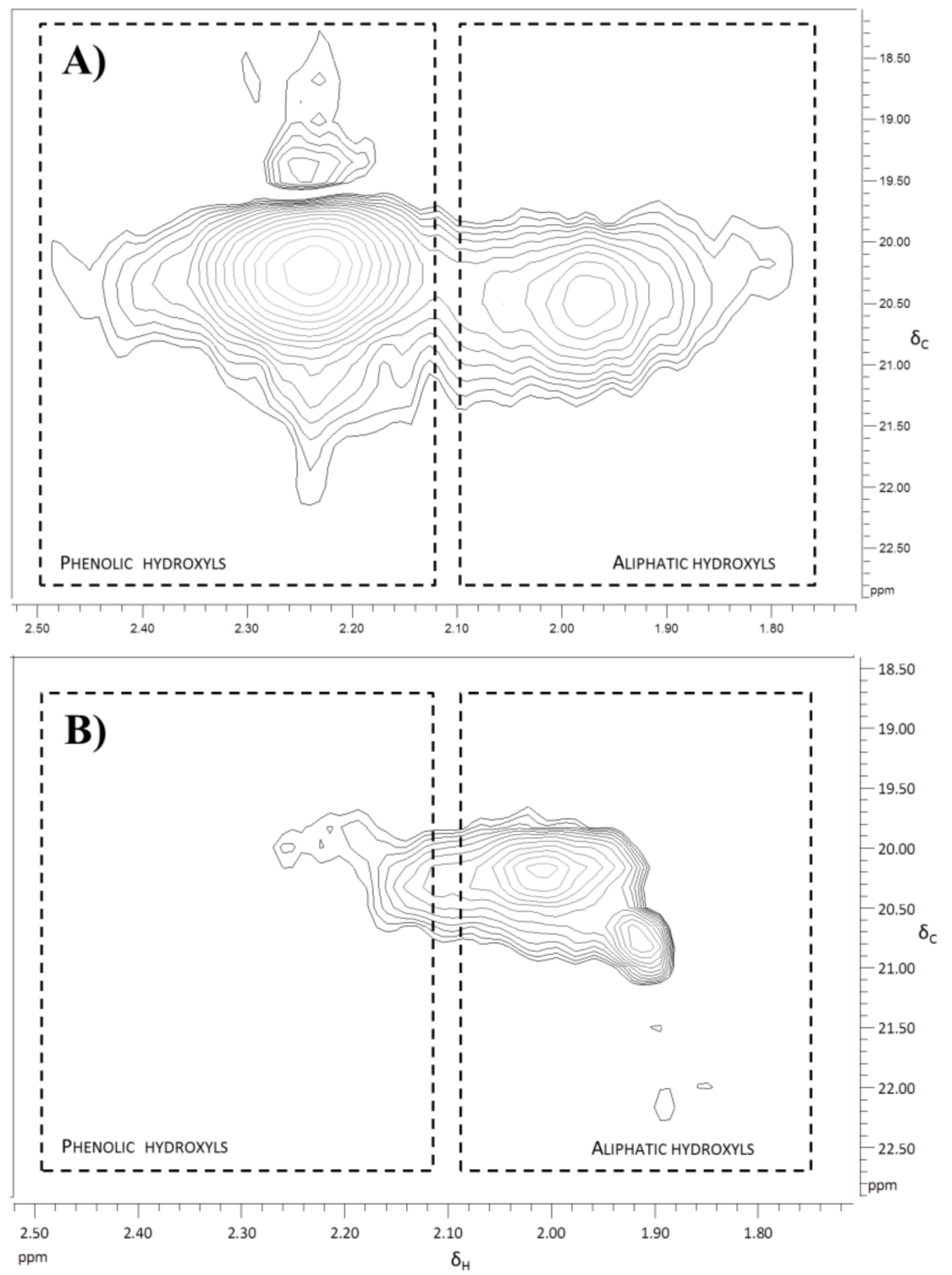

Figure 5. Hydroxyl expanded region of HSQC spectrum of acetylated E. globulus KL: (A) Untreated; (B) After enzymatic polymerization.

${ }^{13} \mathrm{C}$ NMR also revealed significant differences between KL samples (Figure 6). After the enzymatic treatment, a remarkable increase in the signal at $172.0 \mathrm{ppm}$ (carboxyl groups) was accompanied by the disappearance of the signal corresponding to phenolic hydroxyls (168.1 ppm), whereas the weak signals of primary and secondary aliphatic hydroxyls remained almost unchanged (170.0 ppm and $169.4 \mathrm{ppm}$, respectively). On the other hand, after the enzymatic treatment, strong signals of aromatic carbons (160-100 ppm) remained in ${ }^{13} \mathrm{C}$ NMR spectrum proving that benzene rings were not affected in the polymerization. This suggests that the polymerization observed by size-exclusion chromatography could be explained by the laccase mode of action: the enzyme initiated the oxidation of phenolic groups into stabilized radicals that subsequently, undergone radical-radical coupling through phenyl ether-carbon and carbon-carbon links. These new bonds yield to the observed increase in molecular weight without destruction of the aromatic KL backbone. Similar behavior was observed by other authors in the polymerization of commercial lignosulphonates and lignin models by laccase [27,28]. 


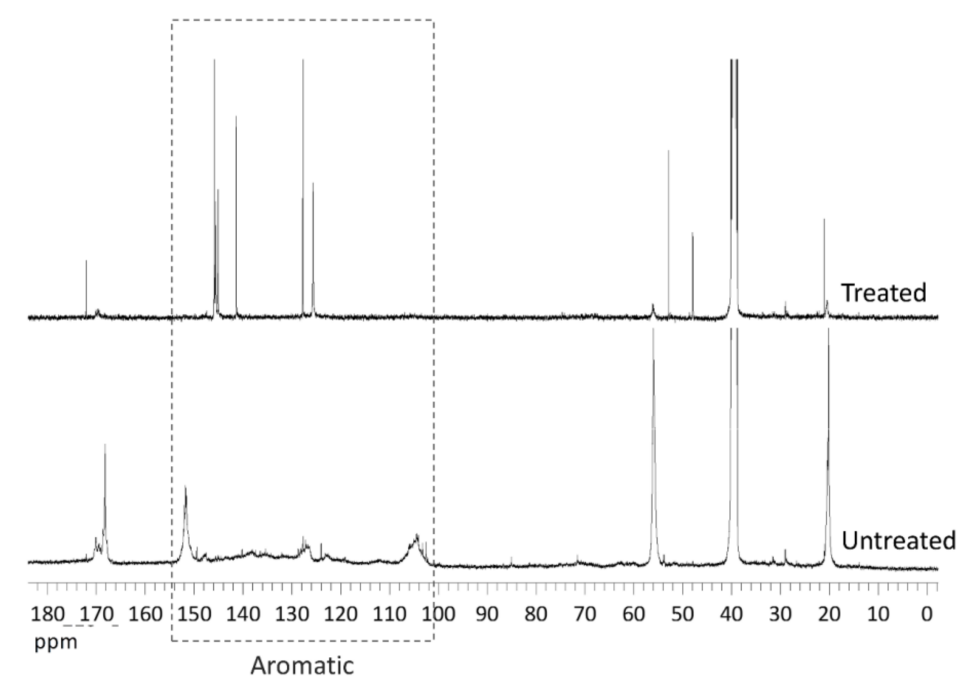

Figure $6 .{ }^{13} \mathrm{C}$ NMR spectra of acetylated E. globulus KL.

\subsection{MDF Manufacture}

Manufacturing of binderless MDF with an enzymatic pre-treatment by dry process were performed under the conditions specified in Table 1. The main objective of these tests was to assess the possible MDF manufacture with only an enzymatic treatment of the wood fibers and/or the addition of KL. The experimental conditions in the MDF manufacturing, such as the amount of enzyme and KL added were adjusted to improve the fiberboard characteristics, maximizing its internal bonding (IB) and minimizing the water absorption and thickness swelling (TS). The dynamic pressing cycle was not optimized in the present study. The temperature and press factor (s. $\mathrm{mm}^{-1}$ board thickness) used during hot pressing were the same used by the industrial partner when testing, in pilot plant, the production of MDF with synthetic resins. These conditions would have to be improved in an industrial scale, since the typical values in the industrial process are around $10 \mathrm{~s}$ pressing time per $\mathrm{mm}$ board thickness.

Nowadays, there are two main industrial processes to obtain high quality wood fibers for MDF manufacturing: thermal and thermo-mechanical pulping process. In both processes, high temperatures and pressure can efficiently defibrate wood, producing a raw material with suitable properties for fiberboard manufacturing [29]. Importantly, the heat associated with high pressures causes chemical changes in the fibers. On one hand, small fragments of lignin are formed in the defibration process, that finally settle in the surface of the fibers. These fragments show a high reactivity due to the presence of phenolic radicals in their structure [30,31]. On the other hand, a glassy layer of hardened lignin is formed on the surface of the fiber because defibration takes place at temperatures above lignin's glass transition temperature [32]. This glassy crust on the fiber surface is a barrier for the enzymatic action in wood fiber's lignin. However, when enzymes are used in the manufacturing process, the initially existing crust is loosened, and lignin is again available for laccase oxidative action. Furthermore, the results found in literature for MDF production, at laboratory and pilot-scale (Table 2), are revealing that laccases can oxidize and polymerize in an efficient way not only isolated lignins, but also lignins in a fiber-bound state. These results indicate that the glassy form of lignin, which covers the wood fibers after defibration, is not able to inhibit, at least completely, the oxidative action of laccase over lignin. 
Table 2. Examples found in literature of binderless MDF glued by auto-adhesion of treated fibers.

\begin{tabular}{|c|c|c|c|c|c|c|c|c|c|c|c|c|c|c|c|c|}
\hline \multirow{2}{*}{ Fiber } & \multicolumn{6}{|c|}{ Incubation Conditions } & \multicolumn{2}{|c|}{ Pressing Conditions } & \multirow[t]{2}{*}{ Scale } & \multicolumn{6}{|c|}{ Board Properties } & \multirow{2}{*}{ Reference } \\
\hline & & Laccase & $\mathrm{T}\left({ }^{\circ} \mathrm{C}\right)$ & Time (h) & $\mathrm{pH}$ & $\begin{array}{c}\text { Enzyme Dosage } \\
\left(\mathrm{U} \cdot \mathrm{g}^{-1} \text { Fiber) }\right.\end{array}$ & $\begin{array}{l}\text { Press Factor } \\
(\mathrm{s} / \mathrm{mm})\end{array}$ & $\mathrm{T}\left({ }^{\circ} \mathrm{C}\right)$ & & $\begin{array}{l}\text { Density } \\
\left(\mathrm{kg} \cdot \mathrm{m}^{-3}\right)\end{array}$ & $\begin{array}{l}\text { MOE } \\
\text { (GPa) }\end{array}$ & $\begin{array}{l}\text { MOR } \\
\text { (MPa) }\end{array}$ & $\begin{array}{c}\mathrm{IB} \\
\text { (MPa) }\end{array}$ & $\begin{array}{l}\text { WA } \\
(\%)\end{array}$ & TS $(\%)$ & \\
\hline Fagus sylvatica & $\begin{array}{l}\text { Control } \\
\text { Treated }\end{array}$ & $\begin{array}{l}\text { Heat deactivated } \\
\text { Trametes versicolor }\end{array}$ & 20 & 1.0 & 5 & $\begin{array}{c}0 \\
3.5\end{array}$ & 100 & 200 & Lab. & $\begin{array}{l}850 \\
895\end{array}$ & $\begin{array}{l}3.42 \\
4.02\end{array}$ & $\begin{array}{l}25.3 \\
41.7\end{array}$ & $\begin{array}{l}0.91 \\
1.57\end{array}$ & $\begin{array}{l}143 \\
72\end{array}$ & $\begin{array}{l}45 \\
19\end{array}$ & [9] \\
\hline Fagus sylvatica & $\begin{array}{l}\text { Control } \\
\text { Treated }\end{array}$ & $\begin{array}{l}\text { Untreated } \\
\text { M. thermophila }\end{array}$ & 50 & 0.5 & 7 & $\begin{array}{l}0 \\
6 \\
24 \\
\end{array}$ & 25 & 200 & Pilot & $\begin{array}{l}820 \\
858 \\
868\end{array}$ & $\begin{array}{l}\text { (b) } \\
3.70 \\
3.95\end{array}$ & $\begin{array}{l}\text { (b) } \\
40.1 \\
46.0\end{array}$ & $\begin{array}{l}0.33 \\
0.82 \\
0.93\end{array}$ & $\begin{array}{l}224 \\
109 \\
92 \\
\end{array}$ & $\begin{array}{c}146 \\
69 \\
46 \\
\end{array}$ & [4] \\
\hline $\begin{array}{l}\text { Leaf sheath from } \\
\text { commercial plants }\end{array}$ & Treated & $\begin{array}{c}\text { Untreated } \\
\text { Aspergillus oryzae }\end{array}$ & 30 & 1.0 & 6 & $\begin{array}{c}0 \\
6 \\
12 \\
24\end{array}$ & 160 & 200 & Lab. & $\begin{array}{l}1100 \\
1100 \\
1100 \\
1100\end{array}$ & $\begin{array}{c}1.3 \\
13.3 \\
268.3 \\
218.8\end{array}$ & $\begin{array}{l}13.3 \\
17.5 \\
18.6 \\
18.7\end{array}$ & $\begin{array}{l}- \\
- \\
-\end{array}$ & $\begin{array}{l}268.3 \\
82.4 \\
79.7 \\
80.5\end{array}$ & $\begin{array}{c}218.8 \\
67.5 \\
31.4 \\
30.1\end{array}$ & [6] \\
\hline $\begin{array}{l}\text { P. sylvestris }(90 \%) \\
\text { P. radiata }(10 \%)\end{array}$ & $\begin{array}{l}\text { Control } \\
\text { Treated }\end{array}$ & $\begin{array}{l}\text { Heat deactivated } \\
\text { Trametes villosa }\end{array}$ & $\leq 120$ & $\approx 0.5$ & 6 & $\begin{array}{c}0 \\
100\end{array}$ & 22 & 200 & Pilot & $\begin{array}{l}800 \\
800\end{array}$ & - & $\begin{array}{l}\approx 10 \\
\approx 20\end{array}$ & $\begin{array}{l}\approx 0.1 \\
\approx 0.38\end{array}$ & - & $\begin{array}{l}\approx 122 \\
\approx 62\end{array}$ & [33] \\
\hline Havea brasiliensis & $\begin{array}{l}\text { Control } \\
\text { Treated }\end{array}$ & Trametes villosa & 25 & 1.0 & 5 & $\overline{9}$ & 40 & 200 & Lab. & 750 & $\overline{-}$ & $\overline{9}$ & 0.67 & - & - & [34] \\
\hline $\begin{array}{l}\text { Spruce. }(80 \%) \\
\text { Fir }(20 \%)\end{array}$ & $\begin{array}{l}\text { Control } \\
\text { Treated }\end{array}$ & $\begin{array}{c}\text { Buffer + wax } \\
\text { Trametes villosa }+ \text { wax }\end{array}$ & $\leq 165$ & $\approx 0.5$ & 6 & $\begin{array}{l}100 \\
3.5\end{array}$ & 60 & 200 & Pilot & $\begin{array}{l}850 \\
850\end{array}$ & - & $\begin{array}{l}19 \\
37\end{array}$ & $\begin{array}{l}<0.1 \\
0.32\end{array}$ & - & $\begin{array}{l}32 \\
20\end{array}$ & [35] \\
\hline $\begin{array}{l}\text { Spruce. }(80 \%) \\
\text { Fir }(20 \%)\end{array}$ & $\begin{array}{l}\text { Control } \\
\text { Treated }\end{array}$ & $\begin{array}{c}\text { Buffer } \\
\text { Trametes villosa }\end{array}$ & - & - & 6 & 100 & 12 & 190 & Pilot & 750 & - & $\begin{array}{l}12 \\
20\end{array}$ & $\begin{array}{l}<0.1 \\
0.42\end{array}$ & - & $\begin{array}{l}100 \\
50\end{array}$ & [36] \\
\hline
\end{tabular}

(b) delaminated boards; MOE: modulus of elasticity: MOR: modulus of rupture; IB: internal bonding; WA: water absorption; TS: thickness swell. 
Table 3 summarizes the properties of the binderless MDF manufactured under various experimental conditions. The enzyme dosage was kept constant throughout the tests $(29 \mathrm{U} / \mathrm{g}$ of dry fiber). This value was selected considering our previous studies regarding lignin polymerization [11] and the information available in the literature (Table 2). A control experiment (T1) was performed by adding to the fiber nothing but the necessary water for proper heat conduction, i.e., $10-13 \%$ moisture content. These conditions were set to ensure that the temperature in the center of the board exceeds the lignin glass transition temperature because lignin plasticization have been considered partially responsible for board adhesion [37].

Table 3. Summary of MDF manufacturing conditions and MDF properties.

\begin{tabular}{|c|c|c|c|c|c|c|c|c|c|}
\hline & \multicolumn{9}{|c|}{ Treatment } \\
\hline & \multicolumn{3}{|c|}{ One-Component System } & \multicolumn{6}{|c|}{ Two-Component System } \\
\hline & T1 & T2 & T3 & T4 & T5 & T6 & T7 & T8 & T9 \\
\hline \multicolumn{10}{|l|}{ Treatment } \\
\hline $\mathrm{KL}(\% w / w$ dry fiber $)$ & 0 & 0 & 0 & 15 & 15 & 42 & 42 & 78 & 280 \\
\hline Enzyme dose ( $\mathrm{U} \cdot \mathrm{g}^{-1}$ fiber) & 0 & 29 & 29 & & & & & & \\
\hline Enzyme dose (U.g $\left.{ }^{-1} \mathrm{KL}\right)$ & & & & 0 & 190 & 0 & 190 & 190 & 190 \\
\hline Incubation time $(\mathrm{h})$ & & 2 & 24 & & 2 & & 2 & 2 & 2 \\
\hline \multicolumn{10}{|l|}{ Board properties } \\
\hline Density $\left(\mathrm{kg} \cdot \mathrm{m}^{-3}\right)$ & 661 & 670 & 633 & 697 & 705 & 698 & 688 & 785 & 831 \\
\hline IB (MPa) & $<0.01$ & $<0.01$ & $<0.01$ & $<0.01$ & 0.06 & 0.04 & 0.22 & 0.41 & 0.80 \\
\hline WA (\%) & $\mathrm{D}$ & $\mathrm{D}$ & $\mathrm{D}$ & $\mathrm{D}$ & $\mathrm{D}$ & 134.7 & 76.8 & 60.0 & 27.8 \\
\hline TS (\%) & $\mathrm{D}$ & $\mathrm{D}$ & $\mathrm{D}$ & $\mathrm{D}$ & $\mathrm{D}$ & 55.2 & 14.6 & 7.5 & 5.0 \\
\hline
\end{tabular}

\subsubsection{One-Component System}

According to the results shown in Table 3, the fiber pre-treatment with laccase (T2) did not improve the MDF properties when compared to the untreated control (T1). The increase of the enzymatic treatment time, until $24 \mathrm{~h}$ (T3), did not show any improvement in the IB of the MDF. Furthermore, no dimensional stability was showed by the enzymatically-treated MDFs (both T2 and T3), which completely detached when exposed to water for $24 \mathrm{~h}$. The poor results indicate an issue in the manufacturing conditions.

Among the few publications using dry incubation process for one-component binderless MDF production (Table 2), [9] were able to produce fiberboards with reasonably good characteristics. However, there are some noticeable differences between this study and [9]. One is the fiber source: lignins from different wood species have distinct chemical and physical characteristics, such as syringyl/guaiacyl ratio, phenolic content, molecular weight distribution, etc., that may considerably affect the enzymatic polymerization $[11,38,39]$. Also, the thickness and density of the MDF were very different in both studies, and this may have an important impact on the final MDF properties [40]. In a more recent work [36], Euring et al. were able to achieve MDF with good mechanical properties with an IB and modulus of rupture (MOR) of 0.42 and 20 Mpa respectively, yet, a TS of 50\% was still an issue. To improve the dimensional stability of the fiberboards, the authors tested a laccase-mediator-system. The best results were obtained using 4-hydroxybenzoic acid as mediator, leading to a TS of $19 \%$ and a simultaneous improvement in the mechanical properties. Other authors [35] used a laccase-mediator-system to introduce a water-based wax as hydrophobic agent in the manufacturing of a binderless MDF. Until then, the combined use of hydrophobic agents and enzymes were supposed to be incompatible because the hydrophobic agents coated the fibers hindering the enzymatic access to lignin [4]. However, [35] obtained an MDF with IB as high as $0.9 \mathrm{MPa}$ and TS of $17 \%$ using $1 \%$ of hydrowax in a laccase treatment with vanillic alcohol as mediator.

Other alternative to enhance the MDF properties could be the addition of technical lignin to the fibers before the enzymatic treatment. This is the so-called two-component system. Technical lignins are those obtained after the lignocellulosic pulping process (e.g., KL). These lignins have a molecular 
structure considerably different with respect to native lignin. Moreover, technical lignins will have distinct characteristics in composition and structure depending on the pulping process.

Among the several pulping processes to fragment lignocellulose into their major compounds, hemicellulose, cellulose and lignin, Kraft process is the predominant. During Kraft digestion, depolymerization of native lignin mainly occurs through the extensive cleavage of $\beta-\mathrm{O}-4^{\prime}$ ether bonds. The resulting KL has not only a higher amount of phenolic hydroxyl groups but also, biphenyl and other condensed structures are less formed than in other pulping processes [41]. As the main goal during the Kraft process is to achieve high quality cellulose, the large amount of KL obtained is considered a by-product.

In modern Kraft mills, on-site Kraft lignin burning for steam and energy production ensures not only the energy self-sufficiency of these industrial units but also an energetic surplus. However, the incineration (even with energy recovery) is considered the last option for any by-product valorization. As many of the major Kraft pulp producers are considering the conversion of their units in biorefineries, the valorization of Kraft lignin, which is produced in huge quantities, is crucial. Nowadays, Kraft powder lignin is already widely available in the market for various proposes other than incineration.

Therefore, the high availability and high phenolic content of KL, converts such by-product of the pulp industry in a suitable substrate to be used in laccase-assisted processes such as the manufacturing of eco-friendly binderless MDF.

\subsubsection{Two-Component System}

The two-component system, consisting on the addition of E. globulus KL and laccase to the fibers, was tested for the manufacturing of MDF at pilot-scale. It was expected that the enzymatic treatment enhanced the copolymerization between the added KL and the lignin on the wood fibers. Taking into account that solid E. globulus KL was added to the mixture of wood fibers and enzyme, the enzyme dosage was adjusted (T4-T9) as shown in Table 3. Hence, the enzymatic dosage used is no longer referred to fiber weight but to the amount of added KL (190 U of laccase per $g$ of KL).

In the case of fiberboards composed only by wood fibers and KL (T4), with no enzyme addition, the properties obtained were similar to the control fiberboards (T1), suggesting the non-significant effect of single KL addition. When laccase was sprayed in the mixture of wood fibers jointly with KL (T5), the cohesion of the board was improved. Such small improvement (IB was $0.06 \mathrm{MPa}$ ) suggests that the laccase-KL system was able to form cross-linking between the wood fiber's lignin and the added KL. However, the water absorption and TS of the MDF were not measurable because the board detached before the end of the analysis.

Previous studies have combined the addition of lignin, or lignin-like phenolic compounds, in a two-component system binder for MDF production [36]. The phenolic groups offered by the added KL are more accessible to enzymatic action than those found within the wood fibers [42]. Thus, the advantage of a two-component system is not limited to provide a larger number of phenolic groups, but also ensure that those phenolic groups are readily available for enzymatic action, enabling the formation of a greater number of phenoxy radicals. In fact, [36], improved the IB of MDF with the addition of lignosulphonates to the enzymatic treatment of wood fibers. Nonetheless, the TS values obtained were still worse than those obtained with urea-formaldehyde resin. Probably, the hydrophilic nature of lignosulphonates led to less favorable results of MDF dimensional stability. Nonetheless, due to its higher hydrophobic character, KL could be an interesting alternative to lignosulfonates for the manufacturing of binderless MDF in a two components system.

The effect of the KL amount added to the manufacturing process of MDF was also assessed, but keeping constant the ratio of enzyme activity per $g$ of added KL. The increase of KL amount added to the enzymatic treatment (T7) of the wood fibers had a remarkable effect. IB was clearly improved (5-fold), indicating that a higher interlinking between both the wood fiber's lignin and the KL was achieved. Moreover, the water absorption and the TS were significantly improved respect to previous 
treatments. Nevertheless, the amount of polymerized KL was not enough to give an optimal protection against water. It is worth noticing that T6 and T7 had the same amount of KL but, laccase was not present in T6. Therefore, there was no enzymatic induced cross-linking between the KL and the lignin moieties in the wood fibers. Furthermore, the decrease in the lignin phenolic groups (which are the hydrophilic groups of lignin) caused by laccase oxidation (Figures 2B, 4 and 6), could considerably contribute to the lower water absorption and TS observed in the MDF of T7.

Given these results, in T8 and T9, the amount of KL was increased even further. As a result, a clear improvement of board properties was obtained, enabling the manufacturing of MDF with both IB and dimensional stability (Figure 7). Moreover, the MDF properties from test T9 were even better than those reported by [36] in a lignin-laccase-mediator-system. It is noticeable that the T9 MDF (KL + laccase with no mediators) showed similar IB but much better TS than [36] results. As it was commented before, the different industrial lignin used in these studies could be the main reason for the different TS results.

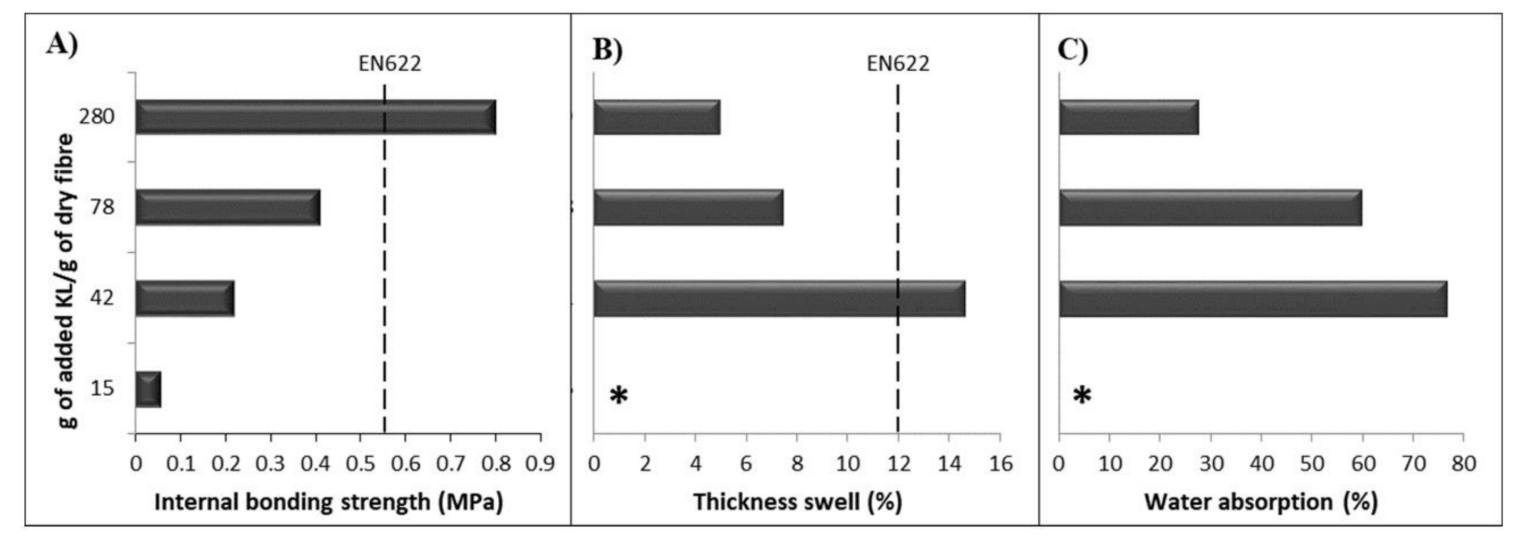

Figure 7. Effect of E. globulus KL addition in MDF properties. In all cases $190 \mathrm{U}$ laccase. $\mathrm{g}^{-1}$ of KL was used. (A) Internal bond; (B) Thickness swell after $24 \mathrm{~h}$ immersion cycle; (C) Water absorption after $24 \mathrm{~h}$ immersion cycle. * Indicates MDF detachment when submersed.

Importantly, T8 and T9 binderless MDFs reached the standards required for indoor application. Such standards depend on the target market, for instance, the American norm for general interior uses, ANSI A.208.2-2002 [43], requires a minimum IB of $0.30 \mathrm{MPa}$ and a TS no higher than $10 \%$ for an MDF Grade 110. The equivalent European standard EN 622-5:2010 [44] is more demanding for IB requirements $(\geq 0.55 \mathrm{MPa})$ but more tolerant for the TS limit $(\leq 12 \%)$. Thus, T9 MDF manufactured in the present study met both the European and American standards for dry environments in both studied properties (IB and TS). This set of tests have proved that it is possible the manufacturing of fiberboards with no synthetic resins. In our tests, the binding among the wood fibers may be attained by the plasticizing effect of the lignin (added lignin and the lignin in the fibers) when heated, and the cross-linking catalyzed by the laccase enzyme. The plasticizing effect of lignin was observed in the tests T4 and T6 with no enzyme. The combination of enzyme and the plasticizing effect of lignin could result in a synergistic effect giving the fiberboard in test $\mathrm{T} 9$ the adequate properties to be marketed.

It is noteworthy that three quarters of T9 MDF weight is composed of E. globulus KL, so it could be considered a lignin-based matrix with wood fibers working as a reinforcing material. Thus, the proposed binderless process of MDF production, in addition to the environmental benefits resulting from the removal of synthetic resins, is a promising pathway of KL valorization, a waste stream of the pulp and paper industry. 


\section{Conclusions}

The oxidation caused by laccase from $M$. thermophila led to a strong polymerization of an isolated industrial KL from E. globulus. Although a significant loss of hydroxyls and aromatic protons was detected by NMR, there was no disruption on the aromatic backbone of the polymer. The use of KL with laccase in a two-component system enabled the manufacturing of MDFs totally free of synthetic resins or additives, with E. globulus as the main raw material. Laccase catalyzed the cross-linking between different lignin molecules forming a 3D structure that confers to the MDF dimension stability, hydrophobicity, and mechanical resistance. The MDFs obtained with laccase + KL (two components system) showed remarkable high internal bonding and low thickness swelling. The boards met the European and American standards for indoor applications. These features and the high availability of KL can make the laccase-assisted polymerization of KL as a fully green strategy to substitute synthetic adhesives in the wood-panels industry.

Supplementary Materials: The following are available online at http:/ / www.mdpi.com/2073-4360/10/6/642/s1, Figure S1: Representation of laccase redox cycle with: A) phenolic substrate; B) phenolic and non-phenolic substrate with a mediator title, Figure S2: Size exclusion chromatogram of untreated KL (blue line) and enzymatically treated KL (Black line), Figure S3: FTIR spectra of untreated KL (blue line) and enzymatically treated KL (Black line).

Author Contributions: S.G. designed and carried out the experiments, analyzed the data and wrote the paper, L.A.O. carried out the experiments, analyzed the data and contributed materials/analysis tools, C.F.-C. carried out the experiments and analyzed the data, D.F. carried out the experiments, and revised the paper, Á.S. contributed materials and revised the paper, D.M. conceived and designed the experiments, analyzed the data and revised the paper.

Funding: This research was funded by [ERDF Funds, Xunta de Galicia] grant number [09TMT012E], [EM2014/041] and [ED431C 2017/47]; [Ministry of Science and Innovation] grant number [CTQ2009-13651]; and by [Fundação para a Ciência e a Tecnologia-Portugal] grant number [POP-QREN BD 42684/2008].

Acknowledgments: Ence (Spain) is gratefully acknowledged for supplying the black liquor. Novozymes (Bagsvaerd, Denmark) is also kindly acknowledged for supplying the laccase from M. thermophila.

Conflicts of Interest: The authors declare no conflict of interest.

\section{References}

1. Kalami, S.; Arefmanesh, M.; Master, E.; Nejad, M. Replacing 100\% of phenol in phenolic adhesive formulations with lignin. J. Appl. Polym. Sci. 2017, 134. [CrossRef]

2. Liu, C.; Zhang, Y.; Li, X.; Luo, J.; Gao, Q.; Li, J. “Green” bio-thermoset resins derived from soy protein isolate and condensed tannins. Ind. Crop. Prod. 2017, 108, 363-370. [CrossRef]

3. Zhang, W.; Ma, Y.; Wang, C.; Li, S.; Zhang, M.; Chu, F. Preparation and properties of lignin-phenol-formaldehyde resins based on different biorefinery residues of agricultural biomass. Ind. Crop. Prod. 2013, 43, 326-333. [CrossRef]

4. Felby, C.; Hassingboe, J.; Lund, M. Pilot-scale production of fiberboards made by laccase oxidized wood fibers: Board properties and evidence for cross-linking of lignin. Enzyme Microb. Technol. 2002, 31, 736-741. [CrossRef]

5. Zhang, D.; Zhang, A.; Xue, L. A review of preparation of binderless fiberboards and its self-bonding mechanism. Wood Sci. Technol. 2015, 49, 661-679. [CrossRef]

6. Álvarez, C.; Rojano, B.; Almaza, O.; Rojas, O.J.; Gañán, P. Self-Bonding Boards From Plantain Fiber Bundles After Enzymatic Treatment: Adhesion Improvement of Lignocellulosic Products by Enzymatic Pre-Treatment. J. Polym. Environ. 2011, 19, 182-188. [CrossRef]

7. Widsten, P.; Kandelbauer, A. Adhesion improvement of lignocellulosic products by enzymatic pre-treatment. Biotechnol. Adv. 2008, 26, 379-386. [CrossRef] [PubMed]

8. Pye, E. Kendall Industrial Lignin Production and Applications. In Biorefineries-Industrial Processes and Products; Wiley Online Books; WILEY-VCH Verlag GmbH \& Co. KGaA: Weinheim, Germany, 2008; pp. 165-200, ISBN 978-3-527-31027-2.

9. Felby, C.; Pedersen, L.S.; Nielsen, B.R. Enhanced auto adhesion of wood fibers using phenol oxidases. Holzforschung 1997, 51, 281-286. [CrossRef] 
10. Kharazipour, A.; Schindel, K.; Hüttermann, A. Enzymatic Activation of Wood Fibers for Wood Composite Production. In Enzyme Applications in Fiber Processing; ACS Symposium Series; American Chemical Society: Washington DC, USA, 1998; Volume 687, pp. 99-115, ISBN 0-8412-3547-3.

11. Gouveia, S.; Fernández-Costas, C.; Sanromán, M.A.; Moldes, D. Polymerisation of Kraft lignin from black liquors by laccase from Myceliophthora thermophila: Effect of operational conditions and black liquor origin. Bioresour. Technol. 2013, 131, 288-294. [CrossRef] [PubMed]

12. Gouveia, S.; Fernández-Costas, C.; Sanromán, M.A.; Moldes, D. Enzymatic polymerisation and effect of fractionation of dissolved lignin from Eucalyptus globulus Kraft liquor. Bioresour. Technol. 2012, 121, 131-138. [CrossRef] [PubMed]

13. Dashtban, M.; Schraft, H.; Syed, T.A.; Qin, W. Fungal biodegradation and enzymatic modification of lignin. Int. J. Biochem. Mol. Biol. 2010, 1, 36-50. [PubMed]

14. Leonowicz, A.; Cho, N.; Luterek, J.; Wilkolazka, A.; Wojtas-Wasilewska, M.; Matuszewska, A.; Hofrichter, M.; Wesenberg, D.; Rogalski, J. Fungal laccase: Properties and activity on lignin. J. Basic Microbiol. 2001, 41, 185-227. [CrossRef]

15. Hofrichter, M. Review: Lignin conversion by manganese peroxidase (MnP). Enzyme Microb. Technol. 2002, 30, 454-466. [CrossRef]

16. Wong, D.W.S. Structure and action mechanism of ligninolytic enzymes. Appl. Biochem. Biotechnol. 2009, 157, 174-209. [CrossRef] [PubMed]

17. Felby, C.; Thygesen, L.G.; Sanadi, A.; Barsberg, S. Native lignin for bonding of fiber boards-evaluation of bonding mechanisms in boards made from laccase-treated fibers of beech (Fagus sylvatica). Ind. Crop. Prod. 2004, 20, 181-189. [CrossRef]

18. Areskogh, D.; Li, J.; Gellerstedt, G.; Henriksson, G. Investigation of the molecular weight increase of commercial lignosulfonates by laccase catalysis. Biomacromolecules 2010, 11, 904-910. [CrossRef] [PubMed]

19. Faix, O. Fourier transform infrared spectroscopy. In Methods in Lignin Chemistry; Springer-Verlag: Berlin/Heidelberg, Germany, 1992; pp. 83-109, ISBN 3-540-50295-5.

20. El Mansouri, N.-E.; Salvadó, J. Analytical methods for determining functional groups in various technical lignins. Ind. Crop. Prod. 2007, 26, 116-124. [CrossRef]

21. European Standards EN 319:1993. Particleboards and Fibreboards-Determination of Tensile Strength Perpendicular to the Plane of the Board; European Commission: Brussels, Belgium, 1993.

22. Huber, D.; Pellis, A.; Daxbacher, A.; Nyanhongo, G.S.; Guebitz, G.M. Polymerization of Various Lignins via Immobilized Myceliophthora thermophila Laccase (MtL). Polymers 2016, 8, 280. [CrossRef]

23. Ortner, A.; Huber, D.; Haske-Cornelius, O.; Weber, H.K.; Hofer, K.; Bauer, W.; Nyanhongo, G.S.; Guebitz, G.M. Laccase mediated oxidation of industrial lignins: Is oxygen limiting? Process Biochem. 2015, 50, 1277-1283. [CrossRef]

24. Fernández-Costas, C.; Gouveia, S.; Sanromán, M.A.; Moldes, D. Structural characterization of Kraft lignins from different spent cooking liquors by 1D and 2D Nuclear Magnetic Resonance spectroscopy. Biomass Bioenergy 2014, 63, 156-166. [CrossRef]

25. Capanema, E.A.; Balakshin, M.Y.; Kadla, J.F. A comprehensive approach for quantitative lignin characterization by NMR spectroscopy. J. Agric. Food Chem. 2004, 52, 1850-1860. [CrossRef] [PubMed]

26. Maniet, G.; Schmetz, Q.; Jacquet, N.; Temmerman, M.; Gofflot, S.; Richel, A. Effect of steam explosion treatment on chemical composition and characteristic of organosolv fescue lignin. Ind. Crop. Prod. 2017, 99, 79-85. [CrossRef]

27. Nugroho Prasetyo, E.; Kudanga, T.; Østergaard, L.; Rencoret, J.; Gutiérrez, A.; del Río, J.C.; Ignacio Santos, J.; Nieto, L.; Jiménez-Barbero, J.; Martínez, A.T.; et al. Polymerization of lignosulfonates by the laccase-HBT (1-hydroxybenzotriazole) system improves dispersibility. Bioresour. Technol. 2010, 101, 5054-5062. [CrossRef] [PubMed]

28. Areskogh, D.; Li, J.; Nousiainen, P.; Gellerstedt, G.; Sipilä, J.; Henriksson, G. Oxidative polymerisation of models for phenolic lignin end-groups by laccase. Holzforschung 2010, 64, 21-34. [CrossRef]

29. Back, E.L.; Salmen, N.L. Glass transitions of wood components hold implications for molding and pulping processes. Tappi 1982, 65, 107-110.

30. Widsten, P.; Laine, J.E.; Qvintus-Leino, P.; Tuominen, S. Effect of high-temperature defibration on the chemical structure of hardwood. Holzforschung 2002, 56, 51-59. [CrossRef] 
31. Widsten, P.; Laine, J.E.; Qvintus-Leino, P.; Tuominen, S. Effect of high-temperature fiberization on the chemical structure of softwood. J. Wood Chem. Technol. 2001, 21, 227-245. [CrossRef]

32. Müller, C.; Kües, U.; Schöpper, C.; Kharazipour, A. Natural Binders. In Wood Production, Wood Technology, and Biotechnological Impacts; Universitätsverlag Göttingen: Göttingen, Germany, 2007; pp. 433-467, ISBN 978-3-940344-11-3.

33. Euring, M.; Rühl, M.; Ritter, N.; Kües, U.; Kharazipour, A. Laccase mediator systems for eco-friendly production of medium-density fiberboard (MDF) on a pilot scale: Physicochemical analysis of the reaction mechanism. Biotechnol. J. 2011, 6, 1253-1261. [CrossRef] [PubMed]

34. Nasir, M.; Gupta, A.; Beg, M.D.H.; Chua, G.K.; Kumar, A. Fabrication of medium density fibreboard from enzyme treated rubber wood (Hevea brasiliensis) fibre and modified organosolv lignin. Int. J. Adhes. Adhes. 2013, 44, 99-104. [CrossRef]

35. Kirsch, A.; Ostendorf, K.; Kharazipour, A.; Euring, M. Phenolics as mediators to accelerate the enzymatically initialized oxidation of laccase-mediator-systems for the production of medium density fiberboards. BioResources 2016, 11, 7091-7101. [CrossRef]

36. Euring, M.; Kirsch, A.; Schneider, P.; Kharazipour, A. Lignin-Laccase-Mediator-Systems (LLMS) for the Production of Binderless Medium Density Fiberboards (MDF). J. Mater. Sci. Res. 2016, 5, 7. [CrossRef]

37. Bouajila, J.; Limare, A.; Joly, C.; Dole, P. Lignin plasticization to improve binderless fiberboard mechanical properties. Polym. Eng. Sci. 2005, 45, 809-816. [CrossRef]

38. Moya, R.; Saastamoinen, P.; Hernández, M.; Suurnäkki, A.; Arias, E.; Mattinen, M.-L. Reactivity of bacterial and fungal laccases with lignin under alkaline conditions. Bioresour. Technol. 2011, 102, 10006-10012. [CrossRef] [PubMed]

39. Van de Pas, D.; Hickson, A.; Donaldson, L.; Lloyd-Jones, G.; Tamminen, T.; Fernyhough, A.; Mattinen, M.-L. Characterization of fractionated lignins polymerized by fungal laccases. BioResources 2011, 6, 1105-1121.

40. Rathke, J.; Sinn, G.; Konnerth, J.; Müller, U. Strain measurements within fiber boards. Part i: Inhomogeneous strain distribution within medium density fiberboards (MDF) loaded perpendicularly to the plane of the board. Materials 2012, 5, 1115-1124. [CrossRef] [PubMed]

41. Lora, J. Industrial commercial lignins: Sources, properties and applications. In Monomers, Polymers and Composites from Renewable Resources; Elsevier: Amsterdam, The Netherlands, 2008; pp. 225-241, ISBN 978-0-08-045316-3.

42. Lund, M.; Eriksson, M.; Felby, C. Reactivity of a fungal laccase towards lignin in softwood kraft pulp. Holzforschung 2003, 57, 21-26. [CrossRef]

43. American National Standard Institute ANSI A.208.2-2002. Medium Density Fiberboard (MDF) for Interior Application; American National Standard Institute: Washington DC, USA, 2002.

44. European Standards EN 622-5:2010. Fibreboards Specifications. Part 5: Requirements for Dry Process Boards (MDF); European Commission: Brussels, Belgium, 2010. 